\title{
E-commerce industry study on the impact in development of the credit system
}

\author{
An Zhengang \\ School of Economic and Management \\ Shengyang Aerospace University \\ Shengyang, China \\ Anzhengang@sau.edu.cn
}

\begin{abstract}
The credit system is a large credit environment for developing the entire e-commerce, including the ecommerce participants, equipment system and government legislation. This paper lists the credit problems in today's ecommerce industry, analyzes the causes of these problems, and then describes how to solve, makes layer-by-layer analysis from the problems existing and affecting participants of the e-commerce development, further explores how to solve these problems step by step from the perspective of each participant, proposes a corresponding solution for each problem, and puts forward measures. In the end, this paper presents matters needing attention when proposing the improvement.
\end{abstract}

Keywords-Credit; E-commerce; Development; Bottleneck; Regulation

\section{INTRODUCTION}

With the rapid development of e-commerce in China and the acceleration of economic globalization, many enterprises have set up their own websites and provide customers with online shopping, making e-commerce rise gradually and integrated into people's lives to become a new business activity pattern.

According to the survey, the impact of social business credit problem in the development process of e-commerce is particularly obvious, which can be even said that the credit and e-commerce complement each other. If handled well, it will greatly speed up the development of ecommerce industry. On the contrary, if not handled well, the credit problem will become a bottleneck of the ecommerce development, which might directly affect the development process of e-commerce industry.

\section{RELATIONSHIP BETWEEN E-COMMERCE INDUSTRY AND CREDIT}

\section{A. Concept of Credit}

\section{1) Concept of Credit}

Credit: refers to a credit form provided by industrial and commercial enterprises to each other and directly associated with commodity trading. It consists of the credit provided by enterprises in the form such as credit sale and installment as well as the credit provided in the form such as down payment on the basis of commodity trading.

2) Current Situation of China's Credit

On the whole, currently China owns a relatively low level of business credit management, which cannot meet the needs of economic development. At present, only $17.6 \%$ of the Chinese enterprises have established the credit management department. Among them, the credit sales management of China's large-sized enterprises (SMEs) is better than small and medium-sized enterprises. In particular, many Top 500 Companies in China have generally established the credit risk system, there are obvious gaps between the SMEs and large-sized enterprises in credit management, and credit risk management and credit sales are still at an early stage.

3) What Is the Credit System?

The credit system refers to the environment of ecommerce development, including the credit and ecommerce law. This paper mainly analyzes the credit system from the perspectives of e-commerce participants, infrastructure mechanisms and e-commerce legislation.

\section{B. Impacts of the Credit System on the Development of E-commerce}

1) High social credit will promote the development of e-commerce

In the online shopping process, people can only choose goods and assess the quality with their own experience. If people have objections to the invisible and intangible online shopping, they can only judge through business description and customer evaluation, and lack trust on sellers.

2) Low social credit will hinder the development of $e$ commerce

It is often said that today's society is a society with "weak" credit and honesty. At earlier stage of China's ecommerce, due to the credit crisis, the development of China's e-commerce was in the state of stagnation and even landslides. Credit restricts the development of ecommerce. According to the survey, China had about 1665 shopping websites early in 2000 , but only 1188 by the end of 2001. However, the number of online shopping websites was off about $30 \%$ within two years. This is because nearly half of sellers used descriptions not conforming to goods or took other fraudulent acts at that time. Consequently, people lacked trust on e-commerce, and did not shop online.

In addition, many sellers now use improper means to gain favorable comments on the network, so that some customers shrink back at the sight of goods with "too" favorable comments. 


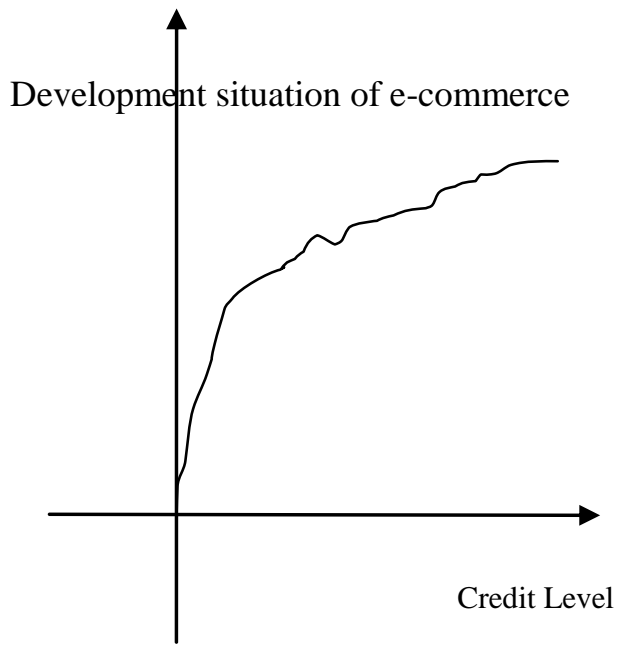

As shown in the figure, the development of ecommerce is positively correlated with the social credit level.

\section{CREDIT PROBLEMS IN CHINA’s E-COMMERCE INDUSTRY}

At present, compared with Western developed countries, China's e-commerce credit environment still lags far behind, and there are still many constraints in the establishment of e-commerce credit guarantee system.

\section{A. Generally lacks credit awareness and credit ethics}

B. Internal e-commerce credit management system is unsound

\section{Credit intermediary services lag behind}

D. China lacks effective legal protection and incentive mechanisms

E. False, unhealthy and even illegal business information are published online

\section{Solution to the CREDIt System's NeGATIVE IMPACTS ON E-COMMERCE}

\section{A. E-commerce Legal Construction}

1) The government makes reasonable e-commerce plans and provides guidance.

When constructing network infrastructure, the government should intensify efforts, reasonably guide the capital investment, improve the investment efficiency, and build a more secure and efficient information network. In terms of e-commerce payment, the government should promote the unified standards and network construction.

2) The government should expand the e-commerce competitiveness

When promoting the e-commerce pattern, the government should make "all flowers bloom together", explore a variety of formats, including both domestic trade and foreign trade, involving both retail industry and wholesale industry.
3) The government should establish some new mechanism applicable to the rapid development of ecommerce

The new mechanisms include online discount mechanism, collaboration mechanism (collaboration of industrial chain, collaboration of payment logistics tools, information platform, payment system, logistics distribution and other collaboration mechanisms), coordination mechanism, outsourcing, hosting mechanism, personnel training mechanism (training of higher education e-commerce, training of adult education ecommerce talents, competition mechanism), e-commerce evaluation mechanism (such as consumer satisfaction scores on Taobao, user satisfaction evaluation system on epayment) and so on.

4) The government should improve the environment of e-commerce development

The government should promote the development of ecommerce, improve and regulate the development process, including the payment process, business credit and industrial credit services. Great importance should be attached to both goods quality and after-sale services. Besides, e-commerce shall focus on credit, so as to make further development.

\section{B. Construction of E-commerce Standards}

China should develop and build the information technology standards, information security standards, product code standards, service code standards and business process standards, regulate the market operating rules, reduce cyber crimes, prevent and eliminate fake and shoddy goods, improve the corporate service quality, and regulate the rights and obligations of operators.

\section{Standardize E-commerce Regulations}

It consists of relevant e-payment system in the trading process between enterprises, sellers and consumers as well as e-commerce statute. China should learn from the advanced experience of foreign countries, regulate the credit card system, and mobilize motivation of the bank, so that cardholders consume via credit cards, which is fast and almost risk-free.

\section{Construction of E-commerce Credit System}

Market economy is a credit commodity economy. Credit is the basis and lifeblood of the market economy, the capital, resources, and even the productivity. Especially in the process of economic globalization, credit is a traffic permit to enter the international market. While Ecommerce is a business activity, credit is also the basis for its existence and development. Besides, due to the remote control, changeability of records, complexity of the subject, e-commerce credit problems become more prominent.

1) In developing e-commerce, importance should be attached to both technology and "commerce"

In the past, greater importance was attached to "technology". Today the development of e-commerce should be fully promoted from the "commercial perspective", so that e-commerce has more vitality. Besides, e-commerce industry should be integrated with traditional enterprises to expand its development space. In promoting e-commerce pattern, the government shall make 
"all flowers bloom together", and boldly explore various patterns.

\section{2) Strengthen the construction of credit system}

In the long planned economic system, China's credit system is far from perfect, people know little about business credit evaluation and personal credit status, which are especially exhibited in e-commerce activities. As a result, good and bad mixed together, seriously restricting the effective implementation of e-commerce activities. The government shall establish sound personal and business credit system, in order to achieve virtual transactions conducted on the specific and reliable basis. If enterprises and individuals with serious adverse credit, they might be disclosed on the network in accordance with relevant laws, so as to purify the trading environment of e-commerce activities.

3) Create a favorable environment for the development of e-commerce, and solve e-commerce security issues

To promote the development of e-commerce, improve and standardize the development process. First of all, have a safe reliable communication network, in order to ensure safe and rapid transfer of transaction information; keep the database server absolute safe. Establish a scientific security system and authoritative e-commerce certification center; continuously improve the security vulnerabilities of protocol and operating system, use the encrypted digital signature to strengthen the universality of network security technical content.

4) Strengthen the making and collaboration of laws, regulations, standards and policies

Make the market mechanism as the guide, follow the principle of taking the easiest and most basic the first, and make laws and regulations on e-commerce. First of all, create a favorable market environment, encourage enterprises to enter the market, accelerate the development of e-commerce market, gradually refine the market rules, formulate e-commerce development plans, standards, policies, and further establish and improve local ecommerce administrative rules and regulations. Secondly, make efforts to improve the administrative law enforcement system of e-commerce, and clarify the responsibilities, division of labor and collaboration.

5) The government should vigorously promote the development of e-commerce

In response to the current momentum of e-commerce activities, the government departments should actively study the characteristics of e-commerce, and rapidly make targeted laws, regulations and policies, so as to regulate ecommerce activities, enhance enterprises and consumers trust on e-commerce. Besides, the government should also attach great importance to coordination with the international e-commerce laws.

\section{MATTERS NEEDING ATTENTION DURING CONSTRUCTION OF FUTURE E-COMMERCE CREDIT SYSTEM}

Market economy is a credit commodity economy. Credit is the basis and lifeblood of the market economy, the capital, resources, and even the productivity. Especially in the process of economic globalization, credit is a traffic permit to enter the international market. While Ecommerce is a business activity, credit is also the basis for its existence and development. Besides, due to the remote control, changeability of records, complexity of the subject, e-commerce credit problems become more prominent. To establish a relatively sound credit system, China might take the following measures:

\section{A. Clarify the Task Divisions and Roles of Government, Enterprises and Individuals}

In China, the market is immature and the corporate reputation is relatively weak. Therefore, when constructing the e-commerce credit system, the government should directly involve with many aspects, for example, electronic authentication needs the the government's credibility for supplementation. From the perspective of China's situation, it is probably currently unrealistic to completely adopt the market competitive manner to develop the electronic certification industry, so the government must be the strong backing of e-commerce credit construction. The government should address the problem of anonymous trading parties. Sellers or consumers are concealed on the network to a certain extent. Any dispute will bring great obstacles to both sides to directly address issues, which will directly affect their credit. In order to ensure the healthy development of e-commerce, it is necessary for the government or authorized agency to act as safety certification authority of electronic signatures.

\section{B. Simultaneously Focus on Technology, Legislation and Ethics}

Technology is the foundation of e-commerce credit construction. Many infidelity behaviors might be prevented or even eliminated through technology. However, from the previous analysis, there are still a lot of technological problems in the construction of e-commerce credit, and these problems can only be solved through relevant laws and regulations. As a result, laws and regulations have become the final constraint mechanism and remedy for many infidelity behaviors. However, it is just a means to constructing the e-commerce credit environment by using technology and law and strengthen the e-commerce construction, which should not be our main purpose. Our main purpose is to create a good credit atmosphere for online trade. Therefore, China must further cultivate the online transactions credit awareness of enterprises and consumers, namely, popularize ecommerce knowledge via educational, online forums, and intensify the advocacy and construction of online credit ethics.

\section{Establish a credit management system}

In order to solve the problem of credit information fragmentation in China, the government should establish a national and global unified, efficient and convenient credit management system

\section{1) Establish a Credit Union}

Trading platform website counterparts with similar functions can set up an information exchange system. Once there are fraudulent and credit events on the trading platform, immediately notify other trading platforms, in order to take preventive measures, add malicious traders into the credit blacklist for publication, and make credit evaluation system more efficient. 
2) Realize nationwide credit information connectivity of all credit bureaus

Regardless of personal credit information or corporate credit information, the system should cover all aspects of social and economic activities, so that people can check the business and personal credit status at any time.

3) Truly link up with personal trading credit

In this regard, we can learn from the practices of Western countries, assign a lifetime valid social security number to each person, which cannot be forged or copied. Besides, the credit company makes a credit report for each person. When conducting online trading, the trading sides can check the other side's credit status at any time. If a person breaches the credit in the transaction, it will be recorded to his/her credit report, and thus affect his/her future transactions.

4) The government should establish information regulatory institution

The government should strictly regulate the product information released by corporate websites and enterprises. The institution mainly monitors the authenticity of the product information released on business websites; the regulatory intermediary institution monitors the authenticity of the product information released by enterprises, and audits the online trading terms of all enterprises. These regulatory measures can avoid the problem of infidelity before trading to a large extent.

\section{Play the roles of third-party intermediaries}

To accelerate the construction of e-commerce trading credit environment, we should also learn from the practices of foreign countries, and strengthen the roles of third-party intermediaries in building e-commerce trading credit environment. Although the involvement of third-party intermediaries might increase the transaction costs of both trading sides and the certification institution has legal effect issues, these do not deny the monitoring and promoting roles of intermediary organizations in the construction of e-commerce credit. In many cases, the law is powerless, and only credit works. It is an integral part of e-commerce trading credit construction to establish the third-party online institution relying on trust mechanisms outside the legal framework.

\section{CONCLUSION}

This paper mainly describes that the development of ecommerce is inseparable from credit guarantee. The establishment of a sound social credit guarantee mechanism and formation of a "honest, ethical" business environment can effectively reduce the risks of business operation, enhance the economic competitiveness of enterprises, protect the trading reliability and security of ecommerce, and promote the rapid development of ecommerce.

The author believes that as long as people can enhance their trusts in e-commerce, actively participate in the construction of credit system as masters and restrain moral behaviors with ethics, sellers abide by the law, there is a unified process and code of conduct, the government launches appropriate legislation and regulates the behaviors of e-commerce activities participants, then ecommerce will develop even faster.

\section{REFERENCES}

[1] Fang Meiqi. Introduction to E-Commerce [M]. Beijing: Tsinghua University Press. 2012

[2] Yu Rengang. Network Economy [M]. Hebei: Hebei People's Publishing House. 2012

[3] Po Xiaolei, Han Jiaping. Corporate Credit Management Model [M]. Beijing: China Foreign Trade and Economic Publishing House. 2011

[4] Yu Jingming, Lin Junyue, Sun Jie. National Credit Management System [M]. Beijing: Social Sciences Documentation Publishing House. 2011

[5] Qu Yunbo. Network Marketing [M]. Beijing: Enterprise Management Press. 2011

[6] Li Qi. E-commerce in China [M]. Sichuan: Southwestern University of Finance and Economics Press. 2011

[7] Li Weichao. Research on Chinese E-commerce Credit System [J] Electronic government. 2012(04)

[8] Guang Lanming. Information Sharing in Credit System Construction [J]. Chinese financial. 2012(02)

[9] Qiao Wei. SME Credit Rating Index System and Model Construction [J]. Henan: Journal of kaifeng University 2011(04).

[10] Zhang Jianguo. Structure of SME Credit Rating System based on Java EE [J]. Computer Digital Engineering. 2010(08)

[11] Xiong Xueping, Zou Jiayong, Wang Xiqin. Analysis Survey on Credit Cooperatives Credit and Information Sharing [J]. China Watch. 2010(04)

[12] Yang Yun. Dynamic Credit Evaluation Model in C2C Transactions [J]. Information Science.2010(04)

[13] Li Huibin, Chen Shi, Cao Guohua. Research on Weight Design between Quantitative Indicators and Qualitative Indicators in Credit Rating [J]. Modern Management Science. 2010(04)

[14] Li Shengmei. SME Financial Management Problems and Countermeasures [J]. Market Modernization. 2010(07)

[15] Li Yan, Du Rong. Application of AHP in B2B E-commerce Platform Usability Evaluation [J]. Technology Management Research.2010(01)

[16] Dai fen, Liu Xiyu, Wang Xiaomin. Application of Colony Neural Network in SME Credit Evaluation [J]. Computer Technology and Development. 2009(10)

[17] Son,J.-Y.and Benbasat. Organizational buyers'adoption and use of B2B electronic marketplaces: Efficiency- and legitimacy-oriented perspectives. Journal of Management Information Systems. 24,1(2012)

[18] Chen, P.Y and Hitt, L.M. Measuring switching costs and the determinants of customer retention in Internet-enabled businesses: A study of the online brokerage industry.Information Systems Research, 13,3(2013),255-274. 